\title{
The analysis of the potential for the use of gaseous fuels in the municipal bus transit in Poland - part 2
}

\begin{abstract}
The paper discusses issues related to the use of compressed natural gas $(C N G)$ in combustion engines particularly in municipal bus transport. The ecological aspects of the use of natural gas in road transport have been analyzed particularly the exhaust emissions in comparison to the emissions from diesel engines. Advantages and disadvantages of natural gas fueling as well as the current level of CNG use in transport have been presented both in Poland and worldwide. The authors have also indicated the motivating arguments for the use of natural gas.
\end{abstract}

Key words: combustion engines, natural gas, bus transport, city buses

\section{Analiza możliwości zastosowania gazowych paliw w miejskim transporcie autobusowym w Polsce - część 2}

\begin{abstract}
W artykule omówiono problematykę wykorzystywania sprężonego gazu ziemnego (CNG) przez silniki spalinowe, przede wszystkim w obszarze miejskiej komunikacji autobusowej. Scharakteryzowano aspekty ekologiczne stosowania gazu ziemnego $w$ transporcie samochodowym, szczególnie w porównaniu z poziomem emisji substancji toksycznych silników ZS. Przedstawiono wady i zalety napędu gazowego, obecny poziom wykorzystania CNG w transporcie zarówno w Polsce, jak i na świecie oraz argumenty motywujace do jego wykorzystania.
\end{abstract}

Słowa kluczowe: silniki spalinowe, gaz ziemny, transport autobusowy, autobusy miejskie

\section{Tests in actual vehicle operating conditions (natural gas fueling)}

As for fueling with natural gas, particularly interesting are the comparative investigations of the exhaust emissions from traditional diesel engines fueled with diesel oil and spark ignition engines fueled with natural gas performed under actual conditions of operation in city traffic. Interesting results are presented in works $[7,8]$. These tests were carried out on a chassis dynamometer in driving tests developed with a view to simulating the city bus drive: Braunschweig (Fig. 7) and Orange County Bus (Fig. 8) [7, 8].

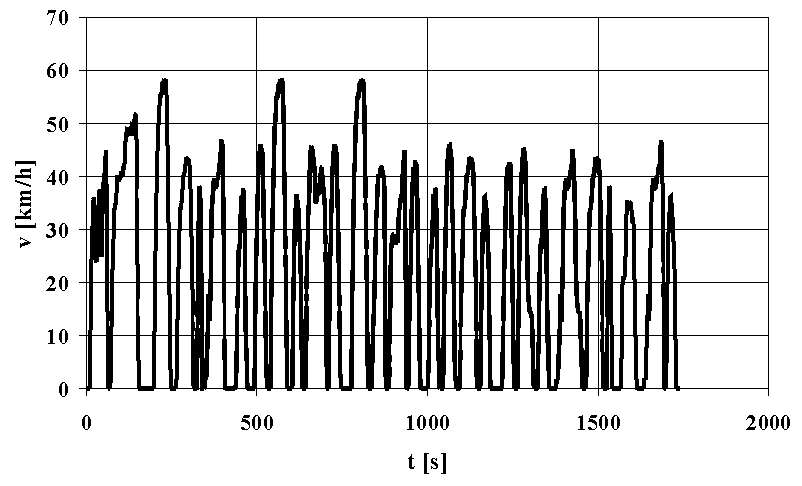

Fig. 7. Braunschweig test diagram

Rys. 7. Schemat testu Braunschweig

The tests were performed on bus engines of different capacities and different controllers of the air-fuel mixture

\section{Badania w rzeczywistych warunkach ruchu pojazdów zasilanych gazem ziemnym}

W kwestii zasilania pojazdów gazem ziemnym szczególnie interesujące są badania porównawcze emisji zanieczyszczeń z silników klasycznych o zapłonie samoczynnym zasilanych olejem napędowym i z silników o zapłonie iskrowym zasilanych gazem ziemnym, wykonywane w warunkach użytkowania autobusu w ruchu miejskim. Interesujące wyniki badań są przedstawione w pracach $[7,8]$. Badania te przeprowadzano na hamowni podwoziowej w testach jezdnych opracowanych w celu symulacji ruchu autobusu miejskiego: Braunschweig (rys. 7) i Orange County Bus (rys. 8) [7, 8].

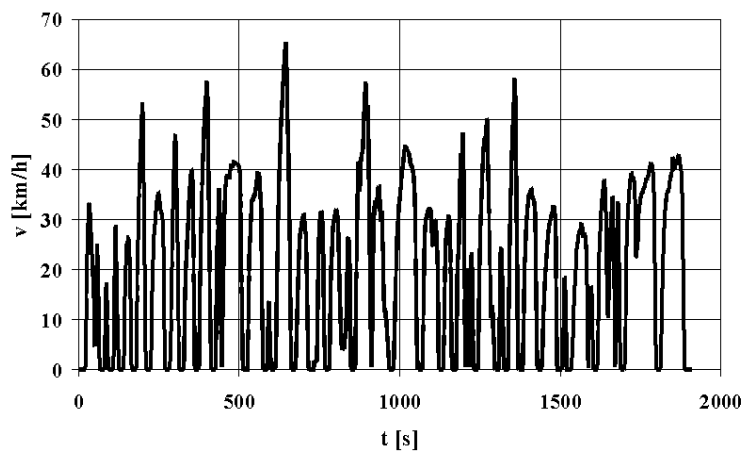

Fig. 8. Orange County Bus test diagram Rys. 8. Schemat testu Orange County Bus

Badania były przeprowadzane na autobusach z silnikami o różnej objętości skokowej i z różnymi układami sterowania 
compositions: controllers set to obtain stoichiometric and lean mixtures. The tests indicated a reduction of the emissions of carbon monoxide and nitric oxides and an almost entire elimination of PM due to the application of natural gas as a fuel. The results for carbon dioxide were ambiguous with a growing trend of the emission level when natural gas was applied. These results confirm the results presented in [9]. In that work the emission of total carbon dioxide was determined (resulting from the elementary fuel composition) from a diesel engine and a spark ignition engine (natural gas fueled) based on the dynamic ETC test results and following the fuel consumption measurement in the MZA test (Fig. 9), developed for the bus traffic conditions in Warsaw. The

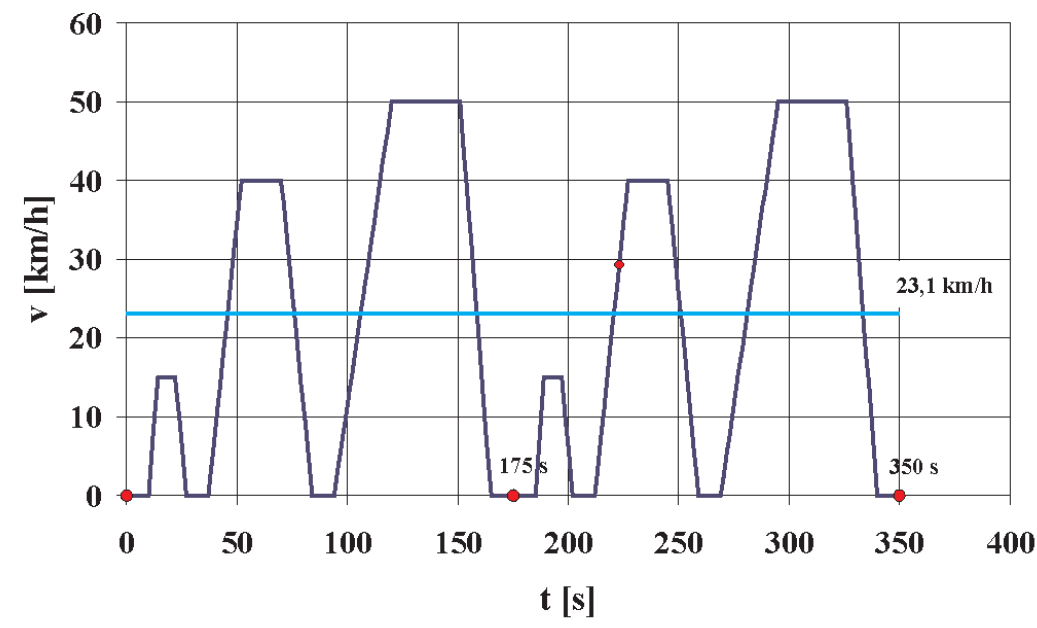

Fig. 9. MZA test diagram (with the average speed marked) Rys. 9. Schemat testu MZA (z zaznaczona wartościa średnia prędkości)

składu mieszanki gazowo-powietrznej: stechiometrycznego i na mieszanki ubogie. Wskazywały one na zmniejszenie, dzięki zastosowaniu gazu ziemnego, m.in. emisji tlenku węgla i tlenków azotu oraz prawie całkowite wyeliminowanie emisji cząstek stałych. Przy emisji dwutlenku węgla wyniki były niejednoznaczne z tendencją zwiększenia się emisji przy zastosowaniu zasilania gazem ziemnym. Wyniki te potwierdzają rezultaty badań przedstawione w pracy [9]. W pracy tej wyznaczono emisję dwutlenku węgla całkowitego (wynikającą ze składu elementarnego paliwa) z silnika o zapłonie samoczynnym na olej napędowy i z silnika o zapłonie iskrowym na gaz ziemny na podstawie wyników badań emisji w teście dynamicznym ETC oraz wyników zużycia paliwa w teście jezdnym MZA (rys. 9), opracowanym dla warunków ruchu autobusów w Warszawie. Wyniki obliczeń wskazały na względne zwiększenie emisji drogowej dwutlenku węgla w sytuacji zastosowania gazu ziemnego o prawie $14 \%$.

Zwiększenie emisji dwutlenku węgla całkowitego przy zastosowaniu gazu ziemnego wynika przede wszystkim z mniejszej sprawności ogólnej silnika o zapłonie iskrowym w stosunku do sprawności ogólnej silnika o zapłonie samoczynnym, szczególnie w warunkach niewielkich obciążeń, co występuje powszechnie w użytkowaniu silników autobusów miejskich. Wniosek odnosnie do różnic w emisji dwutlenku węgla dotyczy jedynie dwutlenku węgla całkowitego - w sytuacji używania biometanu, który jest paliwem odnawialnym; emisja dwutlenku węgla kopalnego jest prawie zerowa, a to właśnie emisja dwutlenku wę-

results of the calculations indicated a relative growth of the road emission of carbon dioxide by almost $14 \%$ if natural gas is applied.

The increase in the emission of total carbon dioxide when using natural gas as a fuel results from a lower spark ignition engine overall efficiency in the first place, particularly under the conditions of low loads, which is common for city buses. The conclusions related to the emission of carbon dioxide pertain only to the total carbon dioxide - in the situation when biomethane is used, which is a renewable fuel, the emission of the fossil fuel originated carbon dioxide is almost zero and it is this particular emission that contributes to the greenhouse effect in the atmosphere [9].

According to publication [10] when comparing the emission from gasoline engines and $\mathrm{CNG}$ engines the following emission reductions take place:

- CO by approximately $70-90 \%$,

- NMHC by approximately $85 \%$,

- $\mathrm{NO}_{\mathrm{x}}$ by approximately $50-80 \%$,

- $\mathrm{CO}_{2}$ by approximately $20 \%$.

In comparison to diesel engines, the use of $\mathrm{CNG}$ reduces the following emissions: gla kopalnego jest czynnikiem sprzyjającym intensyfikacji zjawiska cieplarnianego w atmosferze [9].

Według publikacji [10] przy porównaniu emisji spalin z silników pojazdów benzynowych, w pojazdach zasilanych CNG następuje zmniejszenie emisji:

- CO o ok. $70-90 \%$,

- NMHC o ok. $85 \%$,

- $\mathrm{NO}_{\mathrm{x}}$ o ok. $50-80 \%$,

- $\mathrm{CO}_{2}$ o ok. $20 \%$.

W porównaniu z silnikami ZS, stosowanie CNG zmniejsza emisję:

- CO o ok. $70-90 \%$,

- NMHC o ok. $90 \%$,

- $\mathrm{NO}_{\mathrm{x}}$ o ok. $50 \%$,

- PM o ok. $80-100 \%$,

- $\mathrm{CO}_{2}$ o ok. $20 \%$.

Wydaje się, że powyższe dane nie są jednoznaczne. Wyniki innych badań prowadzonych w Finlandii [11] w 2009 r. na hamowni podwoziowej w teście Braunschweig najnowszych autobusów miejskich (spełniających normę emisji EEF), napędzanych silnikami zasilanymi CNG, potwierdzają korzystniejszą sytuację w aspekcie emisji NOx i PM w porównaniu z emisją tych zanieczyszczeń przez 


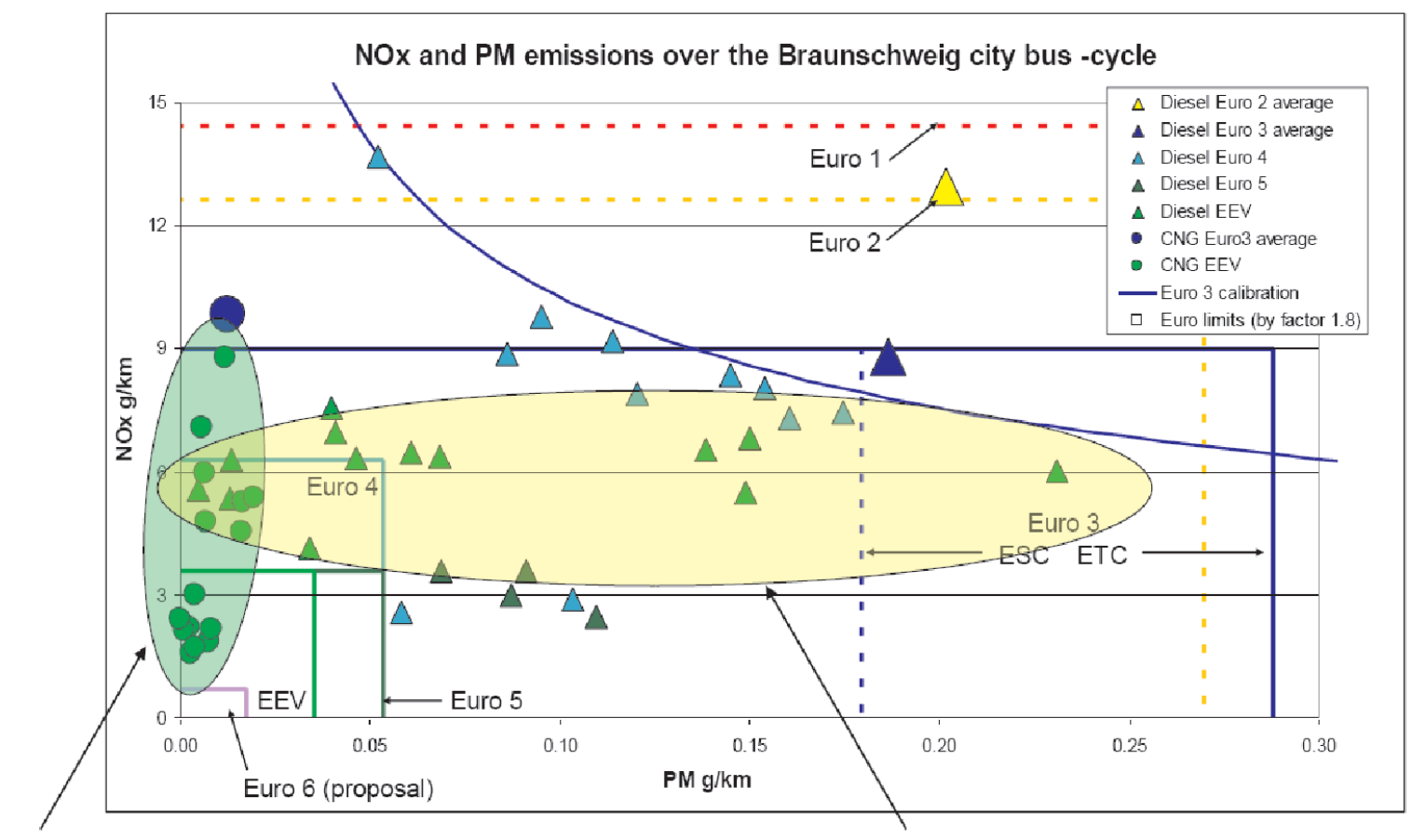

\section{Newest EEV natural gas buses $\quad$ EEV diesel buses}

Fig. 10. Results of the road emission tests from the buses in the Braunschweig test (data from 2009) [11] Rys. 10. Wyniki badań emisji drogowej zanieczyszczeń autobusów w teście Braunschweig (dane z 2009 r.) [11]

- CO by approximately $70-90 \%$,

- NMHC by approximately $90 \%$,

- $\mathrm{NO}_{\mathrm{x}}$ by approximately $50 \%$,

- PM by approximately $80-100 \%$,

$-\mathrm{CO}_{2}$ by approximately $20 \%$. autobusy miejskie z nowoczesnymi silnikami ZS (spełniające normę emisji EEV) - rys. 10.

Jednak emisja drogowa CO i HC np. dla badanych autobusów CNG EEV jest nieco większa niż dla autobusów napędzanych silnikami o zapłonie samoczynnym. Emisja

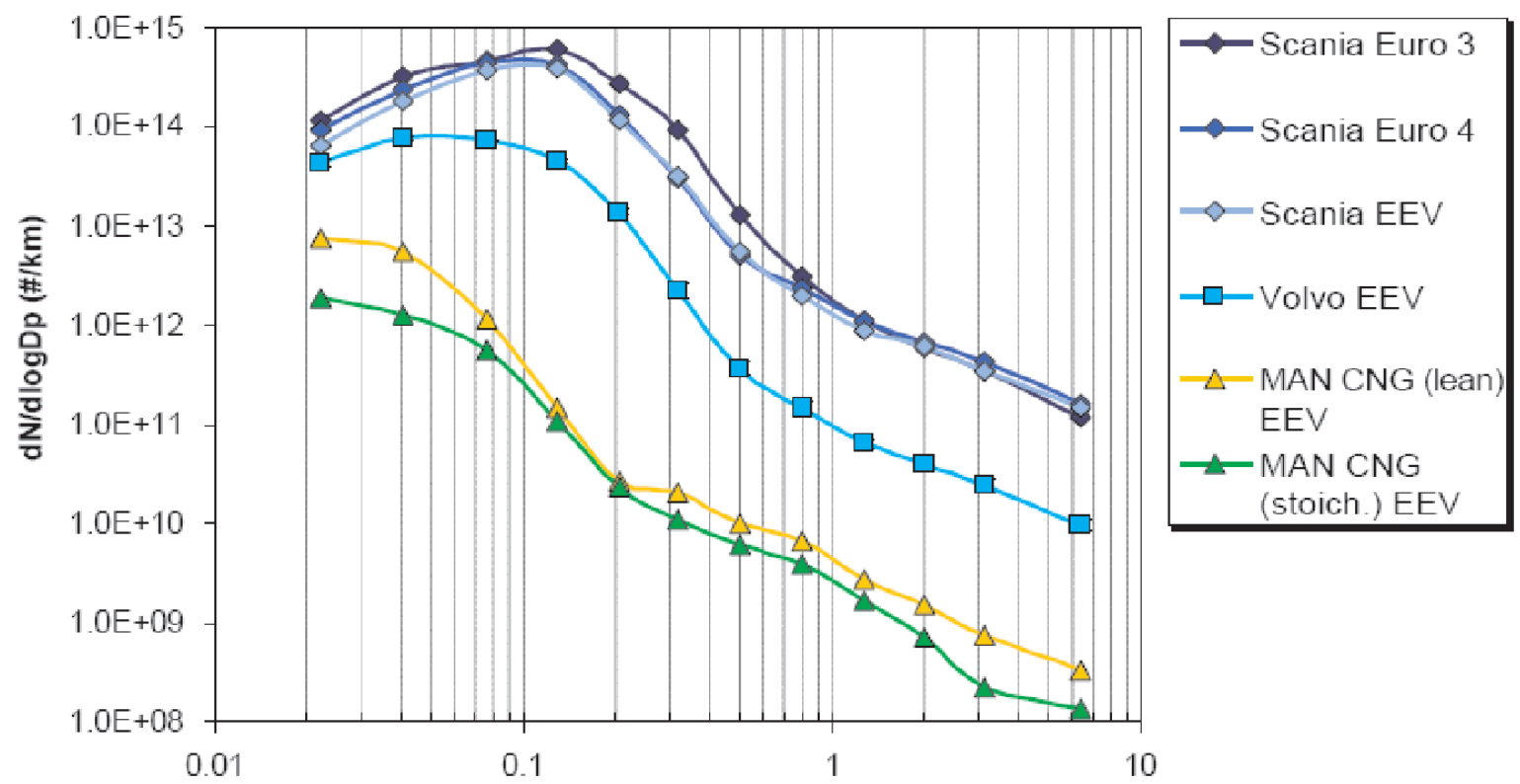

Aerodynamic diameter $(\mu \mathrm{m})$

Fig. 11. Number of particulates in the exhaust gases of the buses examined in the Braunschweig test [11]

Rys. 11. Liczba cząstek stałych w spalinach autobusów badanych w teście Braunschweig [11] 


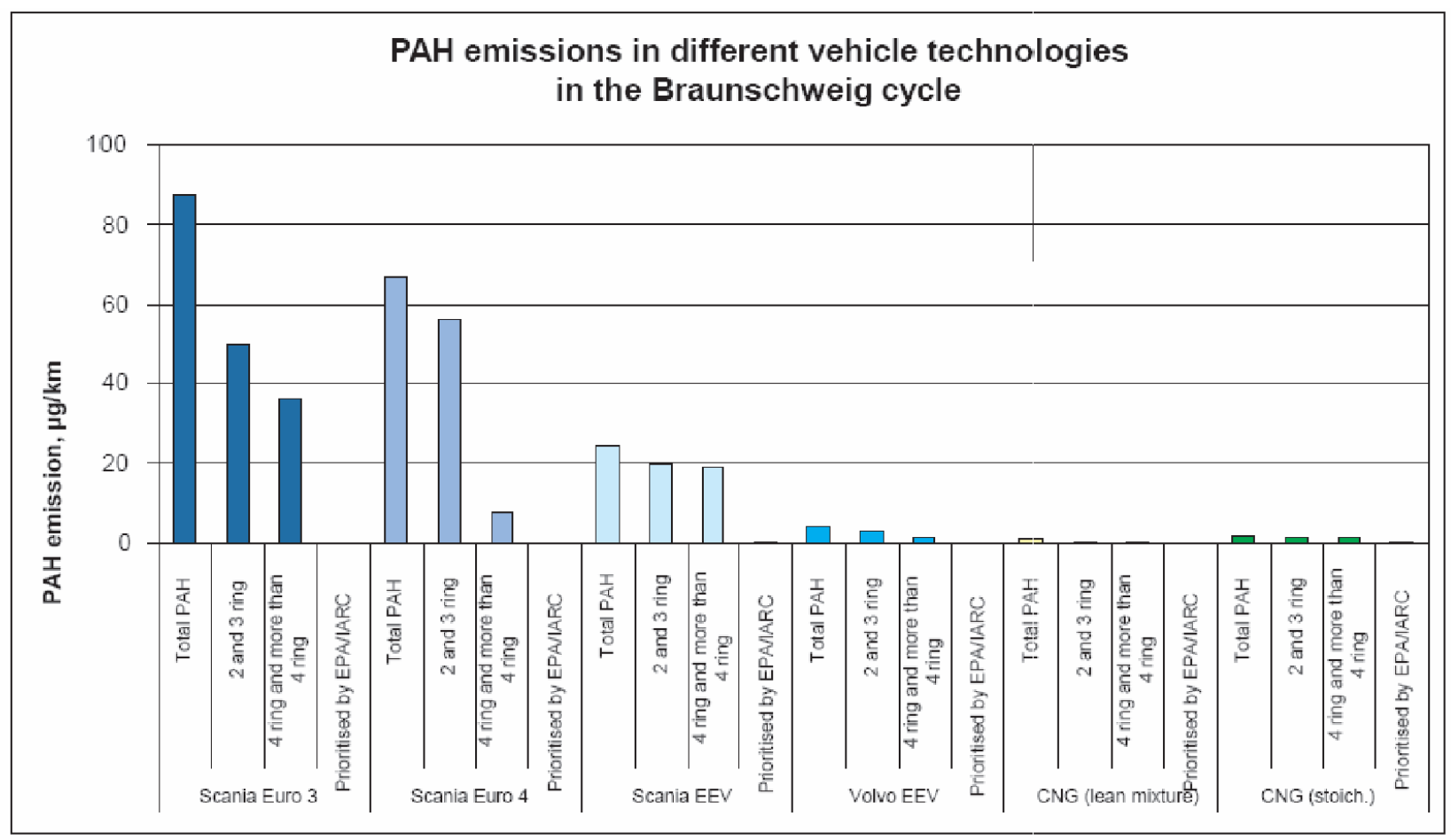

Fig. 12. PAH emission in the Braunschweig cycle [11]

Rys. 12. Emisja PAH w spalinach badanych w teście Brunschweig autobusów [11]

It seems, as thought the above data is not entirely unequivocal. The results of other research conducted in Finland [11] in 2009 on a chassis dynamometer in the Braunschweig test on modern city buses (EEF compliant) fitted with $\mathrm{CNG}$ engines, confirm the more advantageous situation in the aspect of the $\mathrm{NO}_{\mathrm{x}}$ and $\mathrm{PM}$ emission as compared to the emission of these components by modern buses fitted with diesel engines (EEV compliant) - Fig. 10.

Yet, the road emission of $\mathrm{CO}$ and $\mathrm{HC}$ e.g. for the tested CNG EEV buses is a bit higher than it is in the case of buses fitted with diesel engines. The road emission of $\mathrm{CO}_{2}$ is also a bit higher (by approximately 14\%). Using compressed biomethane $\mathrm{CBG}$ instead of $\mathrm{CNG}$, which is almost a $100 \%$ renewable fuel, could eliminate this. This is confirmed by the analyses conducted within the European project Baltic Biogas Bus.

The conclusions from the here presented investigations behoove the authors to state that [11]:

- currently homologated buses fitted with $\mathrm{CNG}$ engines are characterized by a lower emission of $\mathrm{NO}_{\mathrm{x}}$ and $\mathrm{PM}$ and in the case of EEV they preserve the values obtained during homologation that are stable in operation,

- all buses (vehicles) fitted with CNG engines are characterized by a very low emission of PM,

- using methane for fueling of the bus engines (vehicles) provides substantial benefits in terms of PM emission (Fig. 11), aldehyde emissions, PAH (polycyclic aromatic hydrocarbons; Fig. 12) and direct $\mathrm{NO}_{2}$ emission,

- a downside of CNG use is a bit higher energy consumption as compared to diesel oil. drogowa $\mathrm{CO}_{2}$ jest także nieco większa (o ok. 14\%). Można to wyeliminować, stosując zamiast CNG do zasilania silnika autobusu sprężony biometan (CBG), będący niemal w 100\% paliwem odnawialnym. Potwierdzają to analizy prowadzone w ramach europejskiego projektu Baltic Biogas Bus.

Wnioski z przedstawionych tu badań upoważniają m.in. do stwierdzenia, że [11]:

- obecnie homologowane autobusy napędzane silnikami zasilanymi CNG charakteryzują się mniejszą emisją $\mathrm{NO}_{\mathrm{x}}$ i PM, zaś w wykonaniu EEV zachowują wykazywane podczas homologacji wartości emisji zanieczyszczeń, stabilne podczas eksploatacji,

- wszystkie autobusy (pojazdy) napędzane silnikami zasilanymi CNG charakteryzują się bardzo małą emisją PM,

- wykorzystywanie metanu do zasilania silników autobusów (pojazdów) daje znaczące korzyści w postaci małej liczby cząstek stałych (rys. 11), emisji aldehydów, PAH (policyklicznych węglowodorów aromatycznych; rys. 12) i bezpośredniej emisji $\mathrm{NO}_{2}$,

- wadą stosowania CNG jest nieco większe zużycie energii w porównaniu ze stosowaniem $\mathrm{ON}$.

W kwestii ekologiczności paliwa CNG należy jeszcze poruszyć temat hałasu generowanego przez pojazdy NGV. Otóż silniki pojazdów zasilanych CNG pracują znacznie ciszej niż silniki zasilane benzyną czy olejem napędowym. Ma to ogromne znaczenie zwłaszcza w gęstej zabudowie miast, przy dużym natężeniu ruchu drogowego. Prowadzone badania potwierdzają zmniejszenie poziomu hałasu dla pojazdów NGV w granicach $1-3 \mathrm{~dB}$. W praktyce oznacza to, że $\mathrm{z}$ odległości $7 \mathrm{~m}$ od przejeżdżającego pojazdu hałas 
In terms of CNG ecology we also need to discuss the question of noise generated buy NGV vehicles. The engines fueled with CNG are much more quiet than gasoline or diesel engines. This is of particular importance especially in densely populated downtown areas at high traffic congestion. The performed research confirms a reduction of noise of the NGV vehicles from $1-3 \mathrm{~dB}$. In practice that means that from a distance of 7 Meters from a passing bus the noise generated by vehicles fueled with natural gas is $40 \%$ lower as compared to conventional diesel engines.

With its unquestioned ecological advantages natural gas is also one of the cheapest fuels used in transport available in the market.

\section{Potential applications of natural gas in Polish automotive transport}

The potential applications of natural gas in Polish transport are in the following sectors:

- city bus transit- large operators in the fist place,

- private bus carriers,

- taxi corporations,

- mail transport,

- logistics services,

- municipal services (garbage trucks, water trucks),

- railroad - shunting locomotives,

- marine transport - marine engines (including LNG fueled).

\section{The place and the role of the city bus transit in the Polish transport system}

Bus transit is one of the most important elements of the Polish public transport in the cities.

In Poland for the total number of 850 cities, public city transit operates in 300 of them, 280 of which is exclusively bus transit. Throughout the years the use of public transit has been decreasing. In 2009 the public city transit was 3779 million passengers, which was $93 \%$ of the figure from $2008[2,3]$.

The total seating and standing capacity in the public transit vehicles in Poland as at the end of 2009 was 1774,5 thousand, 1283,7 thousand in the buses and 473,6 thousand in the trams. This number has not been drastically changed in recent years.

The bus inventory in the city transit in Poland (city bus operators employing more than 9 persons) as at the end of 2009 was 11755 vehicles. The total mileage of this fleet was 691774 thousand vehicle-kilometers. An average mileage of a single bus per annum was $74537 \mathrm{~km}$.

The highest annual mileage of a city bus in 2009 was in the Mazowieckie province: $80431 \mathrm{~km}$ and the lowest in the Podkarpackie province $-58707 \mathrm{~km}$ at the national average of $74537 \mathrm{~km}$ [4].

\section{Advantages and disadvantages of maintaining of a CNG fleet}

The advantages of the use of $\mathrm{CNG}$ as a fuel are as follows [14-16]: jest mniejszy o ok. $40 \%$ dla pojazdów zasilanych gazem ziemnym $\mathrm{w}$ porównaniu $\mathrm{z}$ pojazdami wyposażonymi $\mathrm{w}$ silniki ZS.

Przy swoich niekwestionowanych zaletach ekologicznych gaz ziemny jest również jednym z najtańszych dostępnych na rynku paliw wykorzystywanych $\mathrm{w}$ transporcie samochodowym.

\section{Potencjalne możliwości zastosowań gazu ziemnego $w$ transporcie samochodowym w Polsce}

Potencjalne możliwości wykorzystania gazu ziemnego w polskim transporcie dotyczą następujących sektorów:

- miejski transport autobusowy - przede wszystkim duże zajezdnie autobusowe,

- prywatni przewoźnicy autobusowi,

- korporacje taksówkowe,

- transport poczty,

- firmy kurierskie,

- gospodarka komunalna (np. śmieciarki, polewaczki),

- kolej-lokomotywy manewrowe,

- transport morski - silniki okrętowe (także zasilane LNG).

\section{Miejsce i rola miejskiej komunikacji autobusowej w polskim systemie transportowym}

Komunikacja autobusowa pozostaje najważniejszym elementem systemu transportu publicznego obsługującego potrzeby przewozowe w polskich miastach.

W Polsce na ogólną liczbę 850 miast, miejska komunikacja publiczna funkcjonuje w 300 miastach, $\mathrm{z}$ tego w ponad 280 miastach oparta jest wyłącznie na transporcie autobusowym. Od wielu lat zmniejszają się przewozy osób środkami miejskiego transportu publicznego. W roku 2009 przewozy pasażerów komunikacją miejską w kraju wyniosły 3779 mln pasażerów, co stanowiło 93\% przewozów w roku 2008 [2, 3].

Ogólna liczba miejsc w pojazdach komunikacji publicznej w Polsce wyniosła wg stanu na koniec 2009 r. 1774,5 tys., w tym 1283,7 tys. miejsc w autobusach i 473,6 tys. miejsc w tramwajach. Liczba ta w ostatnich latach nie uległa zasadniczym zmianom.

Stan inwentarzowy autobusów w transporcie miejskim w Polsce (w przedsiębiorstwach i zakładach komunikacji miejskiej zatrudniających powyżej 9 osób) w końcu 2009 r. wyniósł 11755 pojazdów. Łączny przebieg tego taboru wyniósł 691774 tys. wozokilometrów. Przeciętny przebieg jednego autobusu w ciągu roku wyniósł $74537 \mathrm{~km}$.

Największy średni roczny przebieg autobusu miejskiego w 2009 r. osiągnięto w województwie mazowieckim: 80431 km, a najniższy w województwie podkarpackim - 58707 km, przy średniej krajowej 74537 km [4].

\section{Zalety i wady taboru zasilanego gazem ziemnym}

Jako zalety wykorzystywania gazu ziemnego w transporcie autobusowym wymienia się [14 -16]: 
- low fuel cost in the average cost of 1 vehicle-kilometer as compared to traditional diesel oil,

- lower exhaust emissions,

- reduced engine noise.

The disadvantages of the use of CNG as a fuel are:

- low availability of the fueling stations,

- limited bus range (in kilometers),

- higher purchasing costs of the fleet,

- complicated registration procedures of the buses,

- limited availability of repair shops and spare parts/consumables,

- the threat of reducing of the tax relieves related to gaseous fuel.

\section{Current NGV situation in Poland}

The ideas related to the use of natural gas as a vehicle fuel in Poland have had their history. They have been mostly related to the public bus transit. The first fueling stations were built in the 1950s of the last century (Krosno, Rzeszów, Tarnów, Mysłowice, Zabrze, Gliwice, Sosnowiec, BielskoBiała). A significant input in the development of CNG vehicles had the Sanok Division of the GNiG PGNiG (Polish natural gas provider) that in 1950 and 1960 of the last century had a large fleet of vehicles fueled with CNG (Star, Dodge) for which they had a fueling station in Krosno. In 1970 all stations were disassembled (the last one in Gliwice) due to an adverse ratio of the prices of gasoline and natural gas.

\section{The end of the 1980s and beginning of the 1990s of the} last century

At the end of the 1980 of the last century the ideas of fueling buses with $\mathrm{CNG}$ found its advocates again. Once more, the Sanok facility in 1988 (at its own expense) built a CNG fueling station.

\section{Kraków}

In 1993 professional CNG fueling stations were opened in Krakow (and Warsaw) of the pumping efficiency of 600 $\mathrm{m}^{3} / \mathrm{h}$. In Krakow 6 buses were operated until July 1999. Unfortunately these buses were deteriorated (even 16 years old) and as there was no money for new fleet the project came to an end.

\section{Rzeszów}

Przedsiębiorstwo Transportu Handlu Wewnętrznego (The Domestic Trade Transport Company) in Rzeszow in 1989 became interested in natural gas as a vehicle fuel and 18 used vehicles were converted to CNG fueling (Żuk, Polonez, Star, Fiat). Unfortunately in the time of structural changes PTHW seized to exist and the gasification of the fleet was stopped. In 2004 once again natural gas became of interest in Rzeszów and in March of that year two modern buses were operated on this fuel (Jelcz with composite tanks on the roof).In the Bus depot in Rzeszów at Lubelska Street a public CNG fueling station was opened. The station is owned by the Rzeszów Gas Company; it has a compressor of the efficiency of 300 m3/h - manufactured by an English company AirCom. Later, with the help of NGV Autogas company from Krakow more buses were converted to the CNG fueling.
- niższy koszt paliwa gazowego w średnim koszcie 1 wozokilometra przebiegu w porównaniu z wariantem stosowania oleju napędowego,

- mniejszą emisję substancji szkodliwych do atmosfery,

- mniejszy hałas pracy silnika.

Wadami wykorzystywania gazu ziemnego w transporcie autobusowym są:

- trudny dostęp do stacji tankowania,

- ograniczony zasięg autobusu,

- wyższe koszty zakupu taboru,

- skomplikowana rejestracja autobusów,

- ograniczony dostęp do warsztatów i części wymiennych,

- możliwość ograniczenia ulg podatkowych związanych z paliwem gazowym.

\section{Dotychczasowy rozwój NGV w Polsce}

Zagadnienia wykorzystania gazu ziemnego do napędu pojazdów samochodowych mają w Polsce już kilkunastoletnią tradycję. Z reguły były one i są nadal związane z miejską komunikacją autobusową.

Pierwsze stacje tankowania powstały w połowie lat 50 . ubiegłego wieku (Krosno, Rzeszów, Tarnów, Mysłowice, Zabrze, Gliwice, Sosnowiec, Bielsko-Biała). Istotny wkład w rozwój pojazdów zasilanych gazem ziemnym wniósł Oddział Sanocki Zakładu GNiG PGNiG, który w latach 50. i 60. XX w. miał duży tabor samochodowy zasilany gazem ziemnym (Star, Dodge), i dla których istniała stacja tankowania gazem ziemnym w Krośnie. W latach 70. zlikwidowano wszystkie stacje (ostatnią w Gliwicach) z powodu niekorzystnej relacji cen benzyny w stosunku do cen gazu.

\section{Przełom lat 80. i 90. ubiegłego wieku}

Pod koniec lat $80 . \mathrm{XX}$ w. idea autobusów napędzanych gazem ziemnym znalazła ponownie zwolenników. Również tym razem Sanocki Zakład w 1988 r. (z własnych środków) uruchomił pilotażową stację tankowania pojazdów gazem ziemnym.

\section{Kraków}

W roku 1993 uruchomiono w Krakowie (i w Warszawie) profesjonalne stacje tankowania o wydajności $600 \mathrm{~m}^{3} / \mathrm{h}$. W Krakowie eksploatowano 6 autobusów do lipca 1999 r. Niestety, były to zużyte technicznie autobusy (nawet 16letnie) i wobec braku decyzji o zakupie nowych autobusów eksperyment musiał się zakończyć.

\section{Rzeszów}

W Przedsiębiorstwie Transportu Handlu Wewnętrznego (PTHW) w Rzeszowie w 1989 r. zainteresowano się gazem ziemnym jako paliwem do samochodów i przystosowano do tego celu 18 używanych samochodów (Żuk, Polonez, Star, Fiat). Niestety, w dobie przemian strukturalnych PTHW przestało istnieć, gazyfikację taboru przerwano. W roku 2004 jeszcze raz postanowiono na gaz ziemny w Rzeszowie i od marca 2004 r. rozpoczęto eksploatację 2 nowoczesnych autobusów Jelcz (ze zbiornikami kompozytowymi na dachach), a na terenie bazy MPK w Rzeszowie przy ul. Lubelskiej uruchomiono ogólnodostępną stację tankowania CNG. 


\section{Przemyśl}

The authorities, in collaboration with Sanok PGNiG (natural gas provider) using their own resources of natural gas, developed a comprehensive project 'Przemyśl - a clean city' consisting in the replacement of all city buses with $\mathrm{CNG}$ fueled vehicles. Currently, in Przemyśl there are 15 CNG buses in operation.

\section{Warsaw}

The Warsaw Gas Company once again in 1999 undertook to introduce NGV vehicles on a wide scale based on three principles:

- there would be no CNG conversions in a used bus fleet, - the main objective are technical transport and public transit, - start with 'your own backyard'.

In 1999 a new fueling station was opened and 19 new Gas Emergency vehicles were put into operation (they operate to date).

At the same time as a result of a promotional campaign Warsaw Gas Company began collaboration with PKS Grodzisk Mazowiecki. At the same time in Jelcz, the Jelcz bus manufacturer design works continued on a CNG bus and in September 2000 the first bus was sent to the Warsaw Gas Company and PKS Grodzisk for trials. After the testing period the manufacturer introduced necessary changes and PKS Grodzisk Mazowiecki purchased this first vehicle and as of 1 January 2001 put it into regular operation. The monthly consumption of natural gas by Jelcz CNG was a bit over $2000 \mathrm{Nm}^{3}$. The vehicle consumed on average $43 \mathrm{Nm}^{3}$ of natural gas per $100 \mathrm{~km}$.

\section{Wroclaw}

Wrocław Gas Company upon familiarizing with the Warsaw Gas Company Experiences purchased several Peugeot Partner CNG vehicles and built a fueling station and in 2003 extended the fleet of CNG vehicles. Volvo, having their bus assembly plant in Wrocław, used the CNG Gas Company fueling station. In 2004 within the premises of Wrocław Gas Company a new modern and more efficient $\mathrm{CNG}$ fueling station was opened.

\section{Inowroclaw}

The Inowrocław bus operator in September 2002 built a CNG fueling station that was used by 6 buses including Berliet.

\section{Gdańsk}

The Gas Company in Gdańsk decided to promote natural gas as a vehicle fuel through construction of a CNG fueling station on its premises. 18 Renault Kangoo CNG vehicles were used. The CNG station was opened in 2004.

\section{Zgorzelec}

In Zgorzelec The Gas Company built a two compressor CNG fueling station. Also other CNG stations were constructed in Lubań, Kamienna Góra and Jelenia Góra.

\section{Bielsko-Biala and Tychy}

In 1991 the adaptation of GPW and RAK vehicles for CNG fueling was initiated in FSM Bielsko-Biała. By the end of 1997 in Bielsko-Biała and Tychy 140 of these vehicles
Stacja jest własnością Zakładu Gazowniczego w Rzeszowie; posiada sprężarkę o wydajności $300 \mathrm{~m}^{3} / \mathrm{h}$ - angielskiej firmy AirCom. W kolejnych latach przy pomocy firmy NGV Autogas z Krakowa przystosowano dalsze autobusy miejskie do zasilania CNG.

\section{Przemyśl}

Władze Przemyśla przy współpracy Sanockiego Zakładu PGNiG, wykorzystując własne złoża gazu ziemnego, opracowały kompleksowy program „Przemyśl - czyste miasto”, polegający na wymianie wszystkich autobusów komunikacji miejskiej na pojazdy zasilane gazem ziemnym. Obecnie w Przemyślu w eksploatacji jest 15 autobusów zasilanych CNG.

\section{Warszawa}

Gazownia Warszawska kolejny raz w 1999 r. podjęła próbę szerokiego wprowadzenia pojazdów NGV, opierając się na 3 zasadach:

- żadnych przeróbek instalacji na CNG w użytkowanym, starym taborze,

- główny cel to transport technologiczny i komunikacja miejska,

- rozpoczęcie od „własnego podwórka”.

W roku 1999 uruchomiono nową stację tankowania i do eksploatacji włączono 19 nowych pojazdów pogotowia gazowego, których eksploatacja trwa.

W tym samym czasie w wyniku kampanii promocyjnej Gazownia Warszawska pozyskała do współpracy PKS Grodzisk Mazowiecki. Jednocześnie w Zakładach Autobusowych Jelcz trwały prace konstrukcyjne zmierzające do wyprodukowania autobusu zasilanego CNG i we wrześniu 2000 r. taki autobus został na okres prób powierzony Gazowni Warszawskiej oraz PKS-owi Grodzisk. Po okresie prób fabryka dokonała stosownych modyfikacji, a PKS Grodzisk Mazowiecki zakupił tenże pierwszy autobus i od 1 stycznia 2001 r. skierował do regularnej eksploatacji. Miesięczne zużycie gazu ziemnego przez autobus Jelcz CNG wyniosło nieco ponad $2000 \mathrm{Nm}^{3}$. Autobus zużywał średnio $43 \mathrm{Nm}^{3}$ gazu ziemnego na $100 \mathrm{~km}$ przebiegu.

\section{Wroclaw}

Gazownia Wrocławska po zapoznaniu się z doświadczeniami Gazowni Warszawskiej zakupiła kilka samochodów Peugeot Partner CNG oraz uruchomiła stację tankowania, a w 2003 r. zwiększyła liczbę posiadanych pojazdów CNG. Koncern Volvo posiadający we Wrocławiu montownię autobusów korzystał ze stacji tankowania CNG w Gazowni. W roku 2004 na terenie Gazowni Wrocławskiej przekazano do eksploatacji nową, wydajniejszą stację tankowania CNG.

\section{Inowroclaw}

Przedsiębiorstwo Komunikacyjne w Inowrocławiu we wrześniu 2002 r. uruchomiło stację tankowania autobusów gazem ziemnym, z której korzystało 6 przystosowanych do tego celu autobusów m.in. marki Berliet.

\section{Gdańsk}

Gazownia w Gdańsku zdecydowała się promować gaz ziemny jako paliwo samochodowe poprzez budowę stacji tankowania CNG na terenie Gazowni Gdańskiej. Eksploato- 
were converted. Currently there are several hundred of them. A dramatic improvement of the working conditions in the production halls was obtained and the costs of the adaptation returned after one year.

Natural gas was applied because:

- of easy room ventilation as compared to LPG (Liquefied

Petroleum Gas) because natural gas is lighter than air,

- it has been agreed that natural gas is the safest option,

- natural gas is cheaper than propane-butane (LPG).

\section{Natural gas as an engine fuel in Poland}

In the beginning of 2008 the number of vehicles adapted for compressed natural gas fueling in Poland was estimated at approximately 750 and in 2010 approximately 1800 . The majority were passenger vehicles, light duty trucks (approximately 1500 units) and buses.

In the beginning of 2008 in Poland there were $27 \mathrm{CNG}$ fueling stations. In the end of September 2010 there were 34 operative public CNG stations and stations under construction [15]. Besides, there were 14 non-public CNG stations in Poland.

Out of the generally available CNG stations only 12 were open $24 / 7$.

As of 3 August 2010 in Poland 274 CNG buses serve passengers in 22 Polish cities through 23 carriers: Dębica 6 units, Dzierżoniów 4 units, Elbląg 11 units, Gdynia 14 units, Inowrocław 10 units, Komorniki 2 units, Kraków 5 units, Lublin 2 units, Mielec 7 units, Mysłowice 8 units, Oława 1 unit, Przemyśl 15 units, Radom 39 units, Rzeszów 40 units, Słupsk 5 units, Tarnów 32 units, Toruń 3 units, Tychy 18 units, Wałbrzych 33 units, Wrocław 4 units, Zamość 18 units [16].

Mostly these are domestically manufactured buses: Jelcz with CNG fueling system fitted, imported used Volvo buses from western Europe and Solaris and MAN buses with factory fitted CNG fueling system.

\section{Conclusions}

The environment protection, fuel supply diversification and skyrocketing prices of crude oil in the world markets result in that new energy carriers are sought after in all branches of the economy including transport. Natural gas is one of the energy carriers, whose resources outnumber the ones of crude oil and relative emissions resulting from its combustion are lower than the emission from the combustion of crude oil derivatives.

Natural gas as a fuel used in transport is also characterized by:

- lower price as compared to crude oil fuels,

- lower emission level from engines fueled with this gas,

- lower noise level from the engine fueled with this gas.

The downsides of this fuel are:

- limited number and locations of the fueling stations,

- limited vehicle range (in kilometers) as compared to the range of vehicles fueled with crude oil fuels,

- higher costs of purchasing of the vehicles,

- more complicated vehicle registration procedures,

- somewhat limited availability of repair shops, spare parts and consumables,

- limited tax relieves related to this gaseous fuel. wano 18 samochodów Renault Kangoo CNG. W roku 2004 nastąpiło otwarcie stacji tankowania.

\section{Zgorzelec}

W Zgorzelcu Spółka Gazownicza uruchomiła stację tankowania z dwoma sprężarkami. Uruchomiono też stacje tankowania w Lubaniu, Kamiennej Górze i Jeleniej Górze.

\section{Bielsko-Biala i Tychy}

W roku 1991 rozpoczęto dostosowywanie wózków GPW oraz RAK w FSM Bielsko-Biała do zasilania ich silników gazem ziemnym. Do końca 1997 r. przerobiono w Bielsku-Białej i Tychach 140 wózków. Aktualnie jest ich kilkaset. Uzyskano radykalną poprawę warunków pracy w halach fabrycznych oraz zwrot kosztów adaptacji wózków po jednym roku.

Gaz ziemny zastosowano z uwagi na:

- łatwą w porównaniu z LPG (Liquefied Petroleum Gas) wentylację hal (gaz ziemny jest lżejszy od powietrza),

- uznano, że gaz ziemny jest najbezpieczniejszy,

- fakt, że gaz ziemny był tańszy od propan-butanu (LPG).

\section{Gaz ziemny jako paliwo silnikowe w Polsce}

Na początku 2008 r. liczbę samochodów w Polsce przystosowanych do zasilania sprężonym gazem ziemnym szacowano na około 750, a w 2010 r. na ok. 1800. Większość stanowiły samochody osobowe i dostawcze (ok. 1500 szt.) oraz autobusy.

Na początku 2008 r. w Polsce istniało 27 stacji tankowania CNG. W końcu września 2010 r. były w Polsce 34 dostępne publiczne stacje tankowania $\mathrm{CNG}$ oraz stacje $\mathrm{w}$ budowie [15]. Oprócz tej liczby w Polsce funkcjonowało 14 stacji tankowania CNG niedostępnych publicznie.

Spośród ogólnodostępnych stacji tankowania CNG jedynie 12 było czynnych przez całą dobę.

Według stanu na dzień 3 sierpnia 2010 r. w Polsce 274 autobusy zasilane CNG obsługują pasażerów w 22 polskich miastach, u 23 przewoźników: Dębica 6 szt., Dzierżoniów 4 szt., Elbląg 11 szt., Gdynia 14 szt., Inowrocław 10 szt., Komorniki 2 szt., Kraków 5 szt., Lublin 2 szt., Mielec 7 szt., Mysłowice 8 szt., Oława 1 szt., Przemyśl 15 szt., Radom 39 szt., Rzeszów 40 szt., Słupsk 5 szt., Tarnów 32 szt., Toruń 3 szt., Tychy 18 szt., Wałbrzych 33 szt., Wrocław 4 szt., Zamość 18 szt. [16].

W większości są to krajowe autobusy marki Jelcz, z zabudowaną instalacją CNG, sprowadzane używane autobusy Volvo z krajów Europy Zachodniej oraz Solarisy czy MAN-y $\mathrm{z}$ instalacją fabryczną.

\section{Podsumowanie}

Przesłanki ochrony naturalnego środowiska człowieka, kwestie dywersyfikacji zaopatrzenia w paliwa oraz zmiany cen ropy naftowej na światowym rynku są przyczyną poszukiwania nowych nośników energii w gospodarce, w tym także w transporcie. Jednym $\mathrm{z}$ nośników energii, którego zasoby przewyższają zasoby ropy naftowej, a względna emisja zanieczyszczeń powstających w wyniku spalania jest niższa od emisji spalin pochodzących ze spalania produktów z ropy naftowej, jest gaz ziemny. 
Albeit, the technology of vehicle propulsion (used particularly in all types of municipal fleets- buses in the first place) with $\mathrm{CNG}$ engines is the technology of the future.

A particularly interesting solution in this case is the use of a substitute of natural gas - its physical and chemical equivalent manufactured from waste material - biomethane. The utilization of municipal waste from waste disposal sites or the sediments from sewage farms is the cheapest option as a result of which a fuel is generated while much burdensome waste is at the same time utilized, as is evidenced by the reports within the European project Baltic Biogas Bus.

The development of gas technologies for the propulsion of means of transport is directly dependent on the policy of the state government, in the fiscal aspect in particular.

Necessary investments in the vehicle fleet and the repair and maintenance infrastructure require clearly defined and stable financial background. The background financial conditions need to be of preferential nature for the users as gas technologies based on biomethane:

- are more environment friendly through both limited exhaust emissions (including noise), and simultaneous utilization of various types of waste,

- result in increased diversification of fuels used in transport and they also contribute to decreasing of the energy dependence on external sources,

- increase the use of agro-technical potential of the Polish farms (in the case of biomethane production from agricultural materials),

- contribute to generating employment in the production replacing the imported fuels,

- facilitate the obtainment of the level of use of renewable energy as set out for Poland by the EU.

It is noteworthy that in the communication of the Commission to the European Parliament, European Council and the European Social-Economic Committee, dated 28 April 2010 [17] biogas (biomethane) is listed, next to electrical energy, hydrogen and mixtures of high liquid biofuel content, as one of the elements of the strategy of realization of the priorities of the Europe 2020 initiative - „Europe efficiently using its resources”. The scheme was adopted on 17 June 2010 on the meeting of the European Council.

A similar stance in the global aspect is presented in the 'Strategy of green growth' developed by OECD.

Besides in [18] it is forecasted that biomethane will be an alternative fuel for passenger vehicles, light duty vehicles, heavy duty urban vehicles and heavy duty long-distance vehicles in a short term (2020), mid term (2030) and long term (2050 - only passenger vehicles - light duty vehicles and heavy duty urban vehicles).

The realization of the European project Baltic Biogas Bus, currently underway in collaboration with Motor Transport Institute will certainly facilitate the use of biomethane in city buses following Sweden or Norway.
Gaz ziemny jako paliwo transportowe charakteryzuje się ponadto:

- niższą ceną $\mathrm{w}$ porównaniu $\mathrm{z}$ cenami paliw ropopochodnych,

- możliwością zapewnienia niższego poziomu emisji zanieczyszczeń z silników zasilanych tym paliwem,

- niższym poziomem emitowanego hałasu przez silniki zasilane tym paliwem.

Do wad napędu silnika gazem ziemnym należą:

- ograniczona w kraju liczba i lokalizacja punktów poboru paliwa,

- ograniczony zasięg pojazdu w porównaniu z zasięgiem pojazdów zasilanych paliwami ropopochodnymi,

- wyższe koszty zakupu pojazdów,

- bardziej skomplikowana procedura rejestracji pojazdów,

- w pewnym stopniu ograniczony dostęp do warsztatów i części wymiennych,

- ograniczenia ulg podatkowych związanych z paliwem gazowym.

Nie zmienia to faktu, że technologia napędu pojazdów samochodowych (szczególnie różnego typu taboru miejskiego, w tym przede wszystkim autobusów) gazem ziemnym jest technologią przyszłościową.

Szczególnie interesującym $\mathrm{w}$ tym względzie rozwiązaniem jest wykorzystanie zamiennika gazu ziemnego - jego fizykochemicznego odpowiednika produkowanego z surowców odpadowych - biometanu. Wykorzystywanie odpadów komunalnych z wysypisk śmieci czy też osadów z oczyszczalni ścieków jest tu najtańszym rozwiązaniem, w wyniku którego powstaje w pełni użyteczne paliwo transportowe przy jednoczesnej utylizacji kłopotliwych odpadów, jak pokazują to m.in. opracowania w ramach europejskiego projektu Balic Biogas Bus.

Rozwój gazowych technologii napędu środków transportowych jest w sposób bezpośredni uzależniony od polityki państwa, w tym przede wszystkim w jej wymiarze fiskalnym.

Niezbędne inwestycje zarówno w tabor, jak i w zaplecze obsługowo-naprawcze wymagają jasno zdefiniowanych i przede wszystkim stabilnych uwarunkowań finansowych. Warunki te powinny mieć charakter preferencyjny, ponieważ technologie gazowe, w tym przede wszystkim oparte na biometanie:

- zapewniają lepszą ochronę środowiska naturalnego zarówno przez ograniczenie emisji zasadniczych toksyn z silników spalinowych (i hałasu), jak również przez utylizację różnego typu odpadów,

- zwiększają dywersyfikację paliw zużywanych przez transport, w tym przyczyniają się do zmniejszenia zależności energetycznej kraju od dostaw zewnętrznych,

- zwiększają (w przypadku produkcji biometanu z surowców rolniczych) wykorzystanie potencjału agrotechnicznego polskiego rolnictwa,

- przyczyniają się do tworzenia nowych miejsc pracy związanych z produkcją zastępującą paliwa importowane,

- ułatwiają osiągnięcie poziomu użytkowania energii odnawialnej wyznaczonego dla Polski przez UE. 


\section{Bibliography/Literatura}

[1] European Project Baltic Biogas Bus.

[2] GUS „Transport. Wyniki działalności w 2009 r.”, s. 78.

[3] GUS „Transport. Wyniki działalności w 2009 r.”, s. 182.

[4] GUS ,Transport. Wyniki działalności w 2009 r.”, s. 179.

[5] NGVA Europe.

[6] Wojciechowski A., Chłopek Z., Gis W., Krupiński M., Menes E., Merkisz J., Waśkiewicz J., Żółtowski A.: Alternative Powertrains City Busse. 2010 International Conference on Electric Vehicles. Warsaw University of Technology, July 2010.

[7] Nylund N.O., Erkkilä K., Lappi M., Ikonen M.: Transit bus emission study: comparison of emissions from diesel and natural gas buses. Research Report PRO3/P5150/04 15.10.2004.

[8] Nylund N.O., Lawson A.: Exhaust emissions from natural gas vehicles. Issues related to engine performance, exhaust emissions and environmental impacts. IANGV Emission Report 2000.

[9] Chłopek Z., Magierski M.: The ecological properties evaluation of the use natural gas engines to buses in accordance to the directive on the promotion of clean and energy-efficient road transport vehicles. VIII International Scientific Conference "Gas Engines 2010".

[10] Michałowski R.: Zasilanie CNG alternatywną dywersyfikacji paliw silnikowych. Dolnośląska Spółka Gazownicza s.p. z o.o. V Seminarium Sieci Naukowo-Gospodarczej „Energia”, Wrocław 2007.02.26.

[11] Nylund N.O.: Environmental benefits with biogas buses. Nordic Biogas Conference. Oslo, 10-12 March 2010.

[12] Podziemski T., Bałut H.: Samochody z napędem CNG, znaczącym segmentem rynku gazu ziemnego? 2004.

[13] Biuletyn Informacyjny ITS nr 1/2006, za: Polska Gazeta Transportowa $\mathrm{nr}$ 49/2005.

[14] Zieliński M.: Zasilanie CNG alternatywą dywersyfikacji paliw silnikowych. Dolnośląska Spółka Gazownicza s.p. z o.o. V Seminarium Sieci Naukowo-Gospodarczej „Energia”, Wrocław 2007.02.26.

[15] www.cng.auto.pl

[16] www.cng.auto.pl/pojazdy/pojazdy-autobusy/pojady-autobusycng-polska

[17] COM (2010) 186

[18] European alternative fuel strategy in the Clean Transport Systems Initiative. JEG “Transport \& Environment”.
Warto przy tym wspomnieć, że w Komunikacie Komisji Parlamentu Europejskiego, Rady i Europejskiego Komitetu Ekonomiczno-Społecznego z 28 kwietnia 2010 r. [17] biogaz (biometan) wymieniony jest obok energii elektrycznej, wodoru i mieszanek o wysokiej zawartości biopaliw płynnych jako jeden z elementów strategii realizacji priorytetów inicjatywy Europa 2020 - „Europa efektywnie korzystająca z zasobów". Program został przyjęty 17 czerwca 2010 r. podczas posiedzenia Rady Europejskiej.

Analogiczne stanowisko w wymiarze globalnym prezentuje przygotowywana przez OECD ,Strategia Zielonego Wzrostu".

Ponadto w publikacji [18] przewiduje się, że biometan będzie alternatywnym paliwem transportowym dla samochodów osobowych - „lekkich” pojazdów, „ciężkich” (miejskich) pojazdów i „ciężkich” (długodystansowych) pojazdów w okresie krótkoterminowym (2020), okresie średnioterminowym (2030) i w okresie długoterminowym (2050 - tylko samochody osobowe - „lekkie” pojazdy i „ciężkie” (miejskie) pojazdy).

Trwająca obecnie z udziałem Instytutu Transportu Samochodowego realizacja europejskiego projektu Baltic Biogas Bus na pewno przybliży możliwości wykorzystania w kraju biometanu do zasilania autobusów komunikacji miejskiej, wzorem chociażby Szwecji czy Norwegii.

Część 1 artykutu została opublikowana $w$ numerze 1/2012 Combustion Engines/Silniki Spalinowe.

\section{Paper reviewed/Artykut recenzowany}

Wojciech Gis, DEng. - Head of Environment Protection Centre in Motor Transport Institute in Warsaw.

Drinż. Wojciech Gis - kierownik Centrum Ochrony Środowiska w Instytucie Transportu Samochodowego $w$ Warszawie.

e-mail:wojciech.gis@its.waw.pl

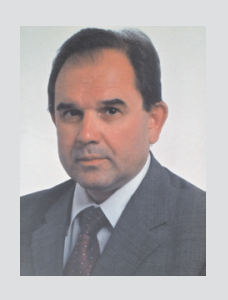

Jerzy Waśkiewicz, DEng. - Head of the Economic Research Department in Motor Transport Institute in Warsaw.

Dr inż. Jerzy Waśkiewicz - kierownik Zakładu Badań Ekonomicznych w Instytucie Transportu Samochodowego w Warszawie.

e-mail: jerzy.waskiewicz@its.waw.pl

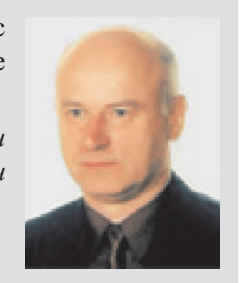
nomic and Planning in Motor Transport Institute in Warsaw.

Dr Edward Menes - zastepca Dyrektora ds. Ekonomiki i Planowania w Instytucie Transportu Samochodowego $w$ Warszawie.

e-mail:edward.menes@its.waw.pl

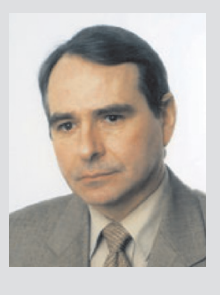

